\title{
Brachycamacina, a new subtribe of the tribe Naupactini (Coleoptera: Curculionidae Entiminae) in Dominican amber
}

\author{
George Poinar, Jr., Andrei A. Legalov, and A.E. Brown
}

\begin{abstract}
A new subtribe (Brachycamacina n. subtribe), genus and species (Brachycamacus gyrommatus gen. n., sp. n.) (Coleoptera: Curculionidae: Entiminae: Naupactini) of weevils are described from Dominican amber. The new subtribe differs from the nominative subtribe of the tribe Naupactini by the following combination of characters: prominent tooth on the profemur, antennae insertions in the middle of the rostrum, all tibiae with mucros, denticulate inner margins of the tibiae, apical two-thirds of the protibiae widened and a very short scape. This represents the second broad-nosed weevil described from Dominican amber.
\end{abstract}

George Poinar, Jr. Department of Zoology, Oregon State University, Corvallis, OR 97331, USA. poinarg@science.oregonstate.edu.

Andrei A. Legalov. Institute of Systematics and Ecology of Animals, Siberian Branch, Russian Academy of Sciences, Frunze Street, 11, Novosibirsk 630091, Russia. fossilweevils@gmail.com

A.E. Brown. 629 Euclid Avenue, Berkeley, CA 94708, USA.

Keywords: Coleoptera; Curculionoidea; Entiminae; new taxa; Dominican amber; Tertiary weevil

\section{INTRODUCTION}

Known as broad-nosed weevils, members of the subfamily Entiminae are somewhat robust non wood-boring weevils that feed and develop mostly on angiosperms. The subfamily is very large, comprising some 12,000 species globally (Morrone, 1999; Oberprieler et al., 2007). Very little is known about the life habits of most species but the biology of many 'pest' species is well known. The larvae are usually root feeders and some members of the subfamily are economic pests (White, 1983; Kuschel, 1995). The earliest fossil of the group (Dorotheus guidensis Kuschel, 1959) dates from the Maastrichtian of Chile (Kuschel, 1959; Legalov, 2012b). A list of fossil Entiminae was published by Yunakov and Kirejtshuk (2011). The Entiminae fauna in amber is fairly extensive. Nine species (Arostropsis groehni Yunakov and Kirejtshuk, 2011, Polydrusus archetypus Zherikhin, 1971, Paonaupactus sitonitoides Voss, 1953, Paonaupactus cephalotes (Voss, 1972), Pro- 
tonaupactus microphthalmus Zherikhin, 1971, Protonaupactus sobrinus (Voss, 1972), Protonaupactus viridis (Wanat and Borowiec, 1986), Archaeosciaphilus marshalli Legalov, 2012a and Archaeocallirhopalus larssoni Legalov, 2013) were described from Late Eocene Baltic amber (Legalov, 2012b, 2013; Voss 1953, 1972; Wanat and Borowiec, 1986; Yunakov and Kirejtshuk, 2011; Zherikhin, 1971). Hypomeces fushunensis Hong, 2002 (Tanymecini) is known from the Late Eocene amber of China (Hong, 2002). Only a single representative, (Promecops tumidirostris Poinar and Brown, 2011), of this widespread subfamily, which is represented in Hispaniola by six tribes and numerous species (Perez-Gelabert, 2008), has been described previously from Dominican amber (Poinar and Brown, 2011). This is in contrast to wood-boring weevils, which are well represented in this deposit (see list of described Dominican amber weevils in Poinar and Legalov (2013). The present study describes a new subtribe of entimine weevils from Dominican amber.

\section{MATERIALS AND METHODS}

The specimen was obtained from La Bucara mine in the Cordillera Septentrional of the Dominican Republic. Dating of Dominican amber is controversial with the latest purported age of 20-15 mya based on Foraminifera (Iturralde-Vinent and MacPhee, 1996) and the earliest of 45-30 mya based on coccoliths (Cêpek in Schlee, 1990). In addition, Dominican amber is secondarily deposited in sedimentary rocks, which makes a definite age determination difficult (Poinar and Mastalerz, 2000). A range of ages for Dominican amber is possible as the amber is associated with turbiditic sandstones of the Upper Eocene to Lower Miocene Mamey Group (Draper et al., 1994). Dominican amber was produced by the leguminous tree, Hymenaea protera Poinar (Poinar, 1991), and a reconstruction of the Dominican amber forest based on amber fossils indicated that the environment was similar to that of a present-day tropical moist forest (Poinar and Poinar, 1999).

\section{SYSTEMATIC PALAEONTOLOGY}

Family CURCULIONIDAE Schoenherr, 1825

Subfamily ENTIMINAE Schoenherr, 1826

Tribe NAUPACTINI Gistel, 1848

Subtribe BRACHYCAMACINA subtrib. $\mathrm{n}$.

http://zoobank.org/25EF5F3E-DC68-4C32-A5B1305DC52ADDA7

Type genus. Brachycamacus gen. $\mathrm{n}$.
Description. Rostrum with prominent oblique scrobes; eyes only slightly distant from base of scrobes, positioned partially on base of rostrum; antennae inserted in middle of rostrum; scape very short; pronotum elongate, postcoxal portion of prothorax longer than precoxal portion; elytra elongate and distinctly convex; greatest width behind middle; first and second abdominal ventrites elongate; profemora with prominent sub-basal tooth; all tibiae with mucros; inner margin of tibiae denticulate; apical two thirds of protibiae widened, with apical comb of setae orientated transversely to tibial axis; claws free, appressed at base.

Diagnosis. The new subtribe differs from other genera of the tribe Naupactini by the profemoral tooth, all tibiae with mucros, denticulate inner margins of the tibiae; antennal insertions in the middle of the rostrum, apical two-thirds of the protibiae widened and a very short scape.

Remarks. The subtribe Brachycamacina falls within the family Curculionidae due to the geniculate antennae with a compact club and elongate 1st and 2nd ventrites. The large mandibles with an apical scar that bear dorsal setae, short rostrum, tibiae with mucros and an apical comb of setae orientated transversely to the tibial axis, suggest placement in the subfamily Entiminae. The new subtribe is placed in the tribe Naupactini based on the prominent oblique lateral antennal scrobes, flat epistomis and free claws.

Genus BRACHYCAMACUS gen. $\mathrm{n}$.

http://zoobank.org/E52B55B6-0423-4ED4-9CB993F0CDCE32DF

Type species. Brachycamacus gyrommatus sp. $\mathrm{n}$. Description. Body black, almost naked; rostrum short, slightly longer than wide, weakly curved, without carinae; scrobes run laterally down to level of eye; forehead wide; eyes large, rounded, distinctly convex; temples elongate; antennal attachment subdorsal; antennae elongate, almost reaching base of pronotum; funicle with 1st-6th antennomeres conical-elongate; club compact; pronotum with weakly rounded sides; pronotal disk distinctly convex, weakly narrowed at apex and base; humeri convex; striae regularly and distinctly punctate; intervals weakly convex, of equal width to striae; apex of elytra separately acuminate; preand postcoxal portions of prothorax short, almost equal in length; metepisternum narrow; abdomen convex ventrally; 1 st and 2nd ventrites equal in length; 5 th ventrite 1.5 times as long as 4th ventrite; legs long; femora weakly clavate, profemora with large sub-basal tooth; trochanters obconical; tibiae 
slightly curved, weakly widened at inner apices, with corbels and mucros; tarsi long; 1st-3rd tarsomeres conical; 5th elongate; tarsomeres with pulvilli on underside; claws free, large, without teeth.

Etymology. The genus name is derived from the Greek words "brachy" (short) and "kamakos" (support) in reference to the short antennal scape.

\section{Brachycamacus gyrommatus sp. $\mathrm{n}$.} Figures 1-5

\section{http://zoobank.org/60ED4AE1-6B56-4655-B891- 05D65CC439CA}

Holotype. Deposited in the Poinar amber collection (accession \# C-7-414) maintained at Oregon State University, Corvallis, Oregon.

Description. Length body, $8.5 \mathrm{~mm}$; length rostrum, $1.2 \mathrm{~mm}$.

Head. Rostrum 0.3 times as long as pronotum, finely and densely punctate; without carinae, with prominent oblique scrobes; forehead flattened, punctate; eyes slightly distant from base; vertex weakly flattened, punctate; temples 1.2 times as long as rostrum and 1.9 as long as eye, punctate; antennae inserted in middle of rostrum; scape quite short, 4.2 times as long as wide, 0.3 times as long as funicle length; 1st antennomere 2.6 times as long as wide, 0.5 times as long as and 0.8 times as narrow as scape; 2nd antennomere 3.8 times as long as wide, 1.2 times as long as 1st antennomere; 3rd antennomere 2.8 times as long as wide, equal in length and width to 2 nd antennomere; 4 th antennomere equal to 3rd antennomere; 5th antennomere 2.0 times as long as wide, 0.9 times as long and 1.3 times as wide as 4th antennomere; 6th antennomere equal to 5th antennomere; 7th antennomere 1.7 times as long as wide, equal in length to 6th, 1.2 times as wide as 6th antennomere; club 0.5 times as long as funicle; 1 st club article elongate, 1.6 times as long as wide, 1.1 times as long and 1.2 times as wide as 7th antennomere; 2nd club article 1.4 times as long as wide, 0.9 times as long as and equal in width to 1 st club article; 3rd club article 1.9 times as long as wide, 1.7 times as long as 1 st club article, tip distinctly acuminate.

Pronotum. Elongate, 1.8 times as long as wide at apex, 1.2 times as long as wide in middle, 1.3 times as long as wide at base; punctate.

Elytra. Elongate and distinctly convex, 2.7 times as long as wide at base, 2.6 times as long as wide in middle, 2.5 times as long as wide at apical fourth; greatest width behind middle, 3.6 times as long as pronotum; humeri convex; strial punctures oval, dense; intervals weakly convex, equal in width to striae; tips acuminate, winged at the margins.

Thorax. Punctate; postcoxal length of prothorax 1.8 times length of precoxal portion; front and middle coxae round to conical, prominent, front coxae contiguous; middle coxae separated by one-third diameter of coxa, hind coxae not transverse.

Abdomen. Third ventrite 0.5 times as long as $2 \mathrm{nd}$ ventrite; 4th ventrite of equal length to 3rd ventrite.

Legs. Long; profemur with large sub-basal tooth; pro- and mesofemora 3.9 longer than wide; metafemora 3.7 longer than wide; tibiae with cluster of elongate, erect setae before apex; apical setal comb orientated transversely to tibial axis; inner margin with row of teeth; apical two thirds of protibiae widened, 12.4 times as long as wide in basal third, 8.5 times as long in middle, 6.5 times as long at apex; mesotibiae 8.5 times longer than wide; metatibiae 8.8 times longer than wide.

Type locality. Amber mine in the northern portion of the Dominican Republic.

Etymology. The specific epithet is derived from the Greek words "gyros" (round) and "ommatos" (eye), in reference to the round prominent eyes.

Remarks. The strongly convex pronotum, all tibiae with mucros, elongate anterior legs, elongate elytra and the profemora with a large sub-basal tooth indicates that the specimen is a male.

\section{DISCUSSION}

Classification of the subfamily Entiminae is controversial (Alonso-Zarazaga and Lyal 1999; Kuschel, 1995; Marvaldi, 1997; Oberprieler et al., 2007; Thompson, 1992; Zherikhin and Egorov, 1991). We follow the system proposed by AlonsoZarazaga and Lyal (1999) who divided the subfamily into 55 tribes, more than 20 of which occur in the New World. Lists of the Neotropical species of Entiminae were published by O'Brien and Wibmer (1982) and Morrone (1999). Representatives of the tribes Anypotactini, Entimini, Eudiagogini, Eustylini and especially Naupactini dominate in the Neotropics. The majority of the tribes (Anypotactini, Cylydrorhinini, Entimini, Eudiagogini, Eustylini, Geonemini, Hormorini, Lordopini, Naupactini, Ophryastini, Sitonini, Thecesternini, Trachyphloeini) are characterized by having free claws, which is an important character (Franz, 2012). Tribes with connate claws such as the Cneorhinini, Peritelini, Polydrusini, Phyllobiini, Sciaphilini and Tropiphorini, are poorly represented in America. The new subtribe is close to the Polydrusini, however it differs from this tribe by all tibiae having mucros and large sub-basal teeth, the antennae 


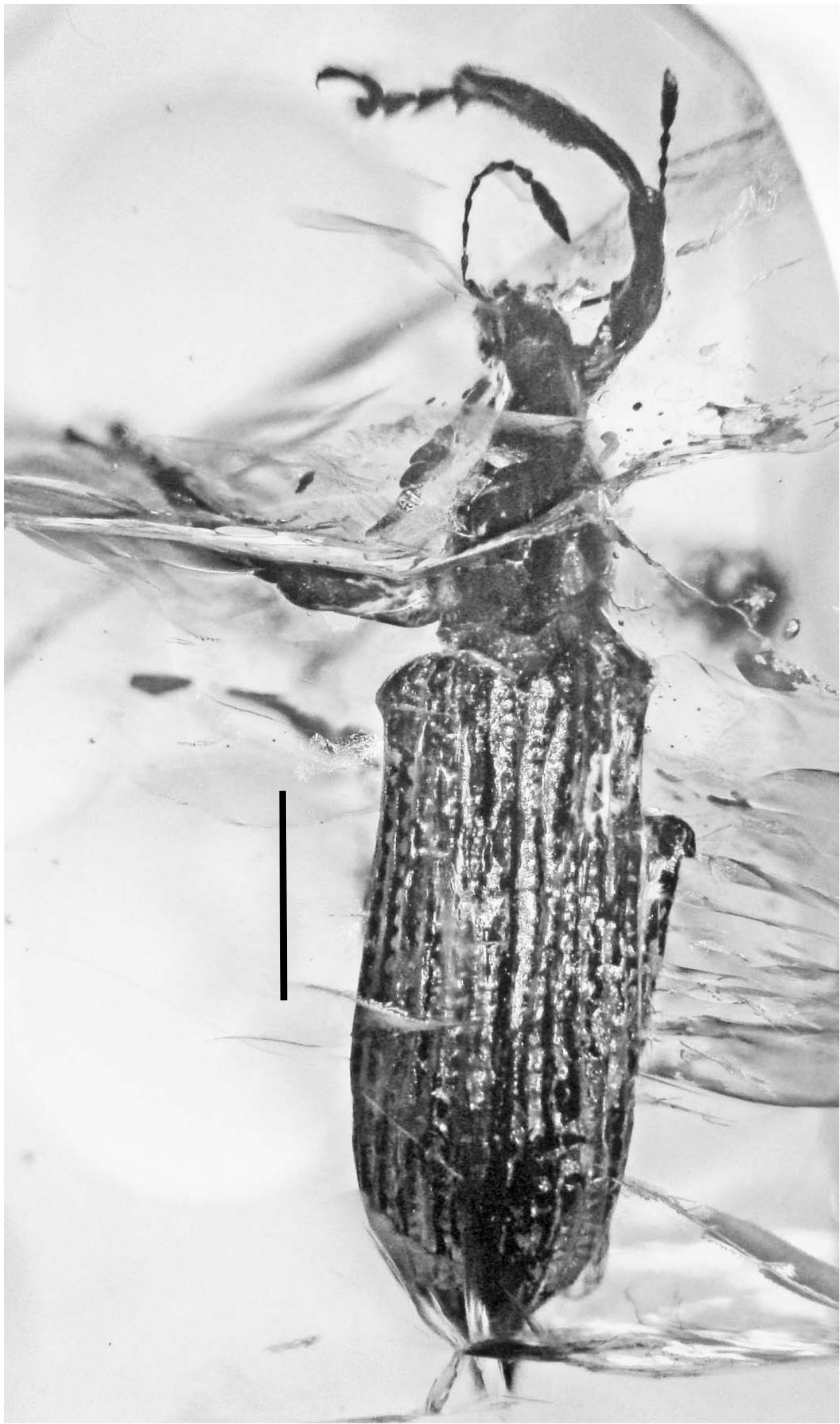

FIGURE 1. Dorsal view of Brachycamacus gyrommatus in Dominican amber. Scale bar equals $1.7 \mathrm{~mm}$. 


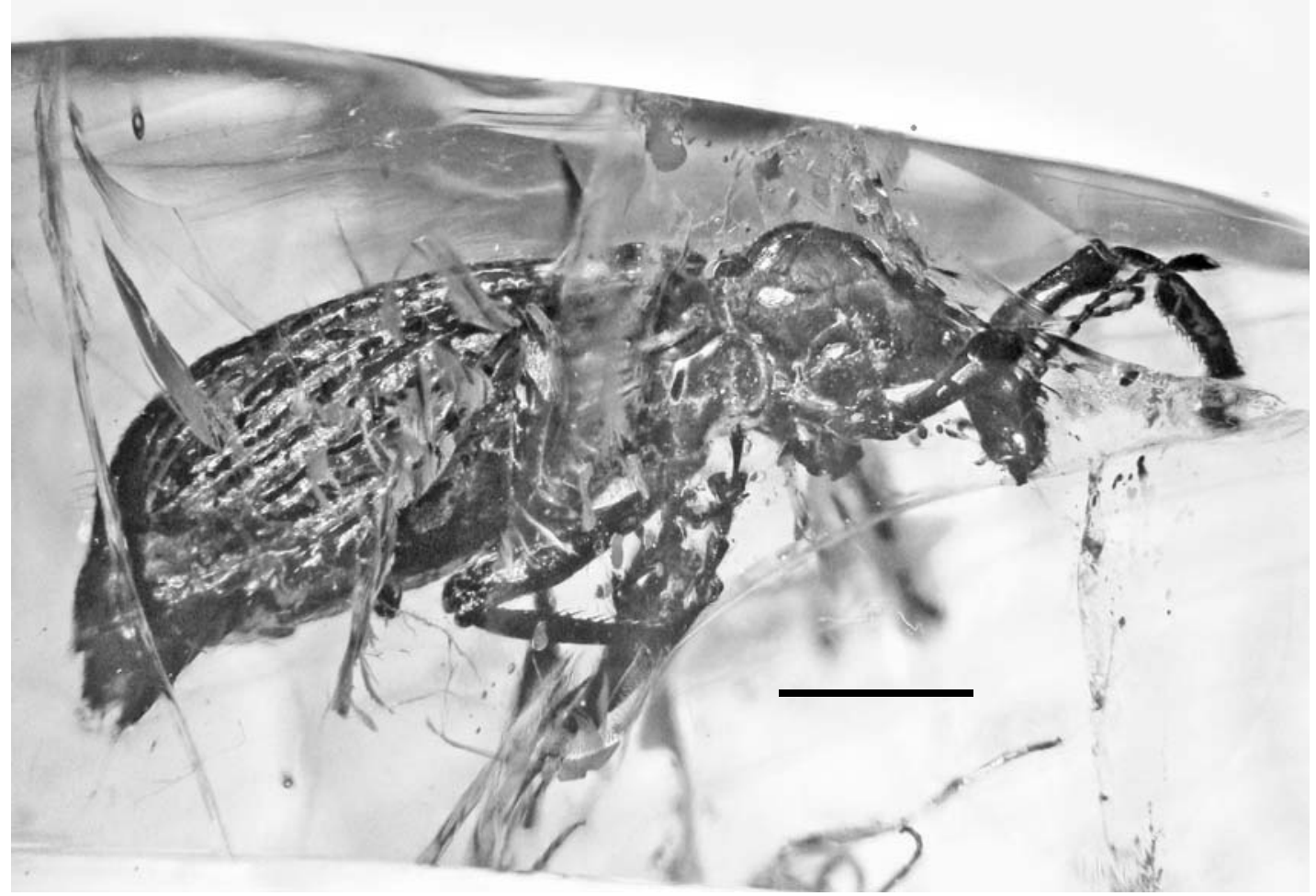

FIGURE 2. Lateral view of Brachycamacus gyrommatus in Dominican amber. Scale bar equals $1.7 \mathrm{~mm}$.

inserted in the middle of the rostrum, the apical two-thirds of the protibiae widened, a very short scape and the elytral apices separately acuminate and winged along the margins. While femora with teeth, as occurs in the new genus, occur in some species in the genera Anypotactus Schoenherr, 1840 (Anypotactini) and Epitosus Sharp, 1891 (Phyllobiini), this condition can be explained by parallelism. Also in the fossil, the profemoral tooth is sub-basal and pointed directly outward, not angled toward the tip of the femur.

\section{ACKNOWLEDGEMENTS}

The study was partially supported by grant no. 12-04-00663-a of the Russian Foundation for Basic Research.

\section{REFERENCES}

Alonso-Zarazaga, M.A. and Lyal, C.H.C. 1999. A world catalogue of families and genera Curculionoidea (Insecta: Coleoptera) (excepting Scolytidae and Platypodidae). Barcelona, Entomopraxis.
Draper, G., Mann, P., and Lewis, J.F. 1994. Hispaniola, p. 129-150. In Donovan S. and Jackson TA. (eds.), Caribbean Geology: An Introduction. The University of the West Indies Publishers' Association, Kingston, Jamaica.

Franz, N.M. 2012. Phylogenetic reassessment of the Exophthalmus genus complex (Curculionidae: Entiminae: Eustylini, Geonemini). Zoological Journal of the Linnean Society, 164:510-557.

Gistel, J. 1848. Faunula monacensis cantharologica. (Fortsetzung). Isis. Enciclopedische Zeitschrift vorzüglich für Naturgeschichte, verglchende Anatomi und Physiologi von Oken. Heft 7. Leipzig. Second to fourth unumbered pages in the Section Umschlag (front covers).

Hong, Y.C. 2002. Amber Insects of China. Beijing Science and Technology Press, Beijing, China. [In Chinese]

Iturralde-Vinent, M.A. and MacPhee, R.D.E. 1996. Age and Paleogeographic origin of Dominican amber. Science, 273:1850-1852.

Kuschel, G. 1959. Un Curculiónido del Cretácao Superior, primer inseto fósil de Chile. Investigaciones Zoológicas Chilenas, 5:49-54.

Kuschel, G. 1995. A phylogenetic classification of Curculionoidea to families and subfamilies. Memoirs of the Entomological Society of Washington, 14:5-33. 


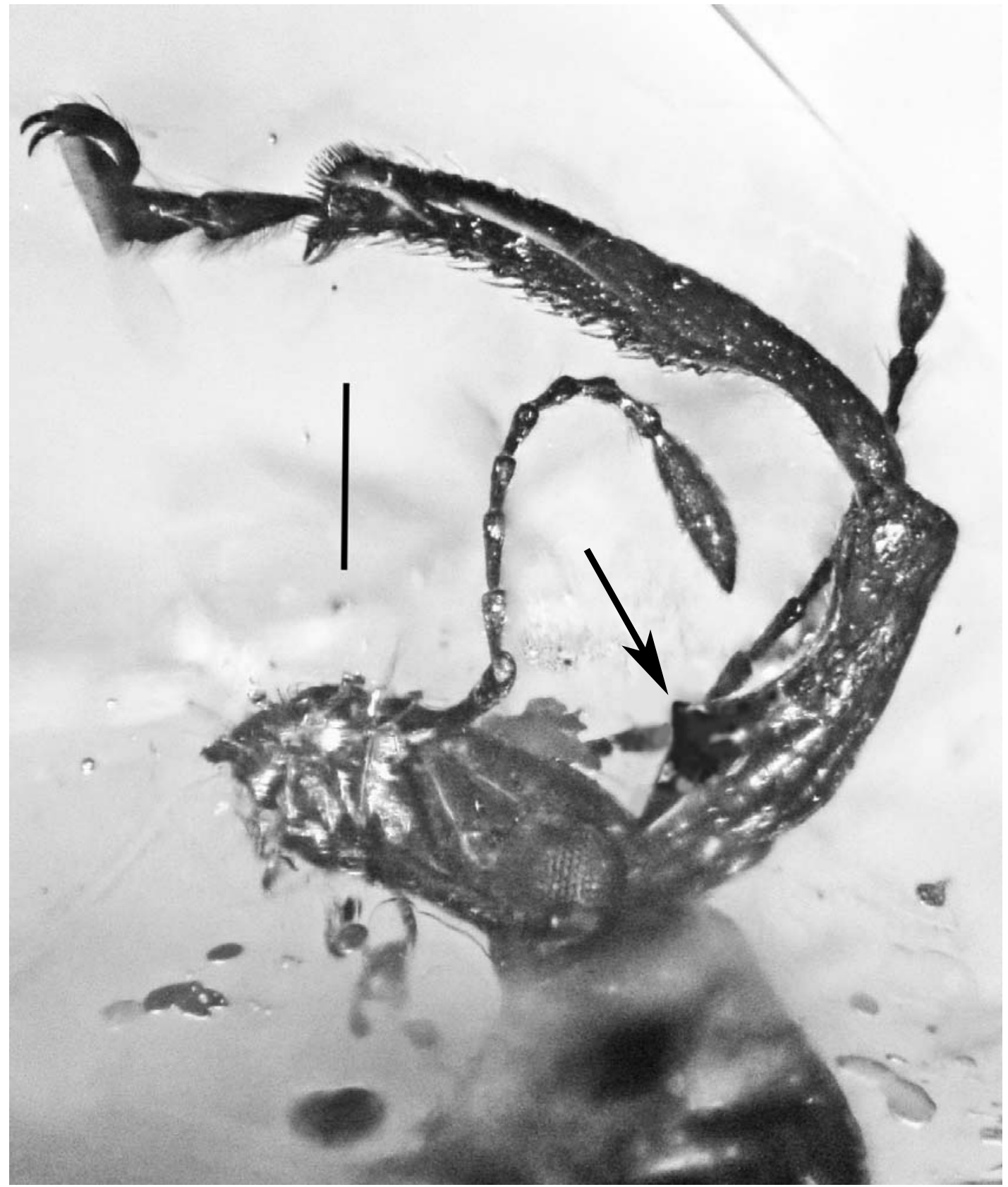

FIGURE 3. Lateral view of head and right foreleg of Brachycamacus gyrommatus in Dominican amber. Arrow shows sub-basal profemoral tooth. Scale bar equals $0.65 \mathrm{~mm}$.

Legalov, A.A. 2012a. New Curculionoid beetles (Coleoptera: Curculionoidea) from the Baltic amber. Paleontological Journal, 46(3):262-272.

Legalov, A.A. 2012b. Fossil history of Mesozoic weevils (Coleoptera: Curculionoidea). Insect Science, 19(6):683-698.

Legalov, A.A. 2013. New and little known weevils (Coleoptera: Curculionoidea) from the Paleogene and Neogene. Historical Biology, 25(1):59-80.
Marvaldi, A.E. 1997. Higher level phylogeny of Curculionidae (Coleoptera: Curculionoidea) based mainly on larval characters, with special reference to broadnosed weevils. Cladistics, 13:285-312.

Morrone, J.J. 1999. The species of Entiminae (Coleoptera: Curculionidae) ranged in America south of the United States. Anales del Instituto de Biología Universidad Nacional Autónoma de México, Serie Zoología, 70:99-168. 


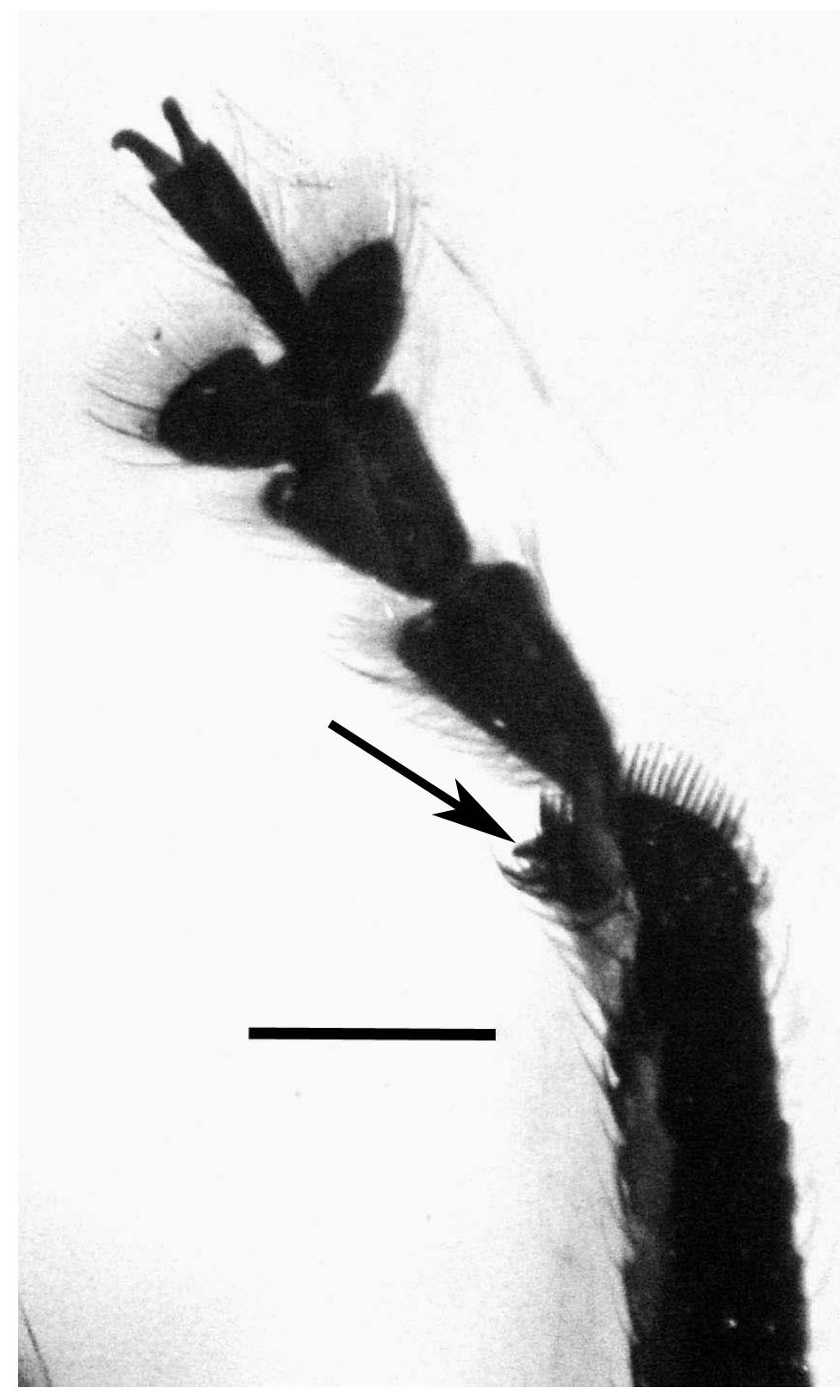

FIGURE 4. Protarsus and apex of protibia of Brachycamacus gyrommatus in Dominican amber. Arrow shows mucro. Scale bar equals $0.5 \mathrm{~mm}$.

O'Brien, C.W. and Wibmer, G.J. 1982. Annotated checklist of the weevils (Curculionidae sensu lato) of North America, Central America, and the West Indies (Coleoptera: Curculionoidea). Memoirs of the American Entomological Institute, 34:1-383.

Oberprieler, R.G., Marvaldi, A.E., and Anderson, R.S. 2007. Weevils, weevils, weevils everywhere. Zootaxa, 1668:491-520.

Perez-Gelabert, D.E. 2008. Arthropods of Hispaniola (Dominican Republic and Haiti): a checklist and bibliography. Zootaxa, 1831:1-530.
Poinar, G.O., Jr. 1991. Hymenaea protera sp.n. (Leguminosae: Caesalpinoideae) from Dominican amber has African affinities. Experientia, 47:1075-1082.

Poinar, G.O., Jr. and Brown, A.E. 2011. Descriptions of a broad-nosed weevil (Eudiagogini: Curculionidae) and false ladybird beetle (Nilionini: Nilionidae) in Dominican amber. Historical Biology, 23:231-235.

Poinar, G.O., Jr. and Legalov, A. 2013. Bicalcasura maculata n. gen., n. sp. (Curculionoidea: Dryophthoridae) with a list of weevils described from Dominican amber. Historical Biology. DOI: 10.1080/ 08912963.2013.786066 


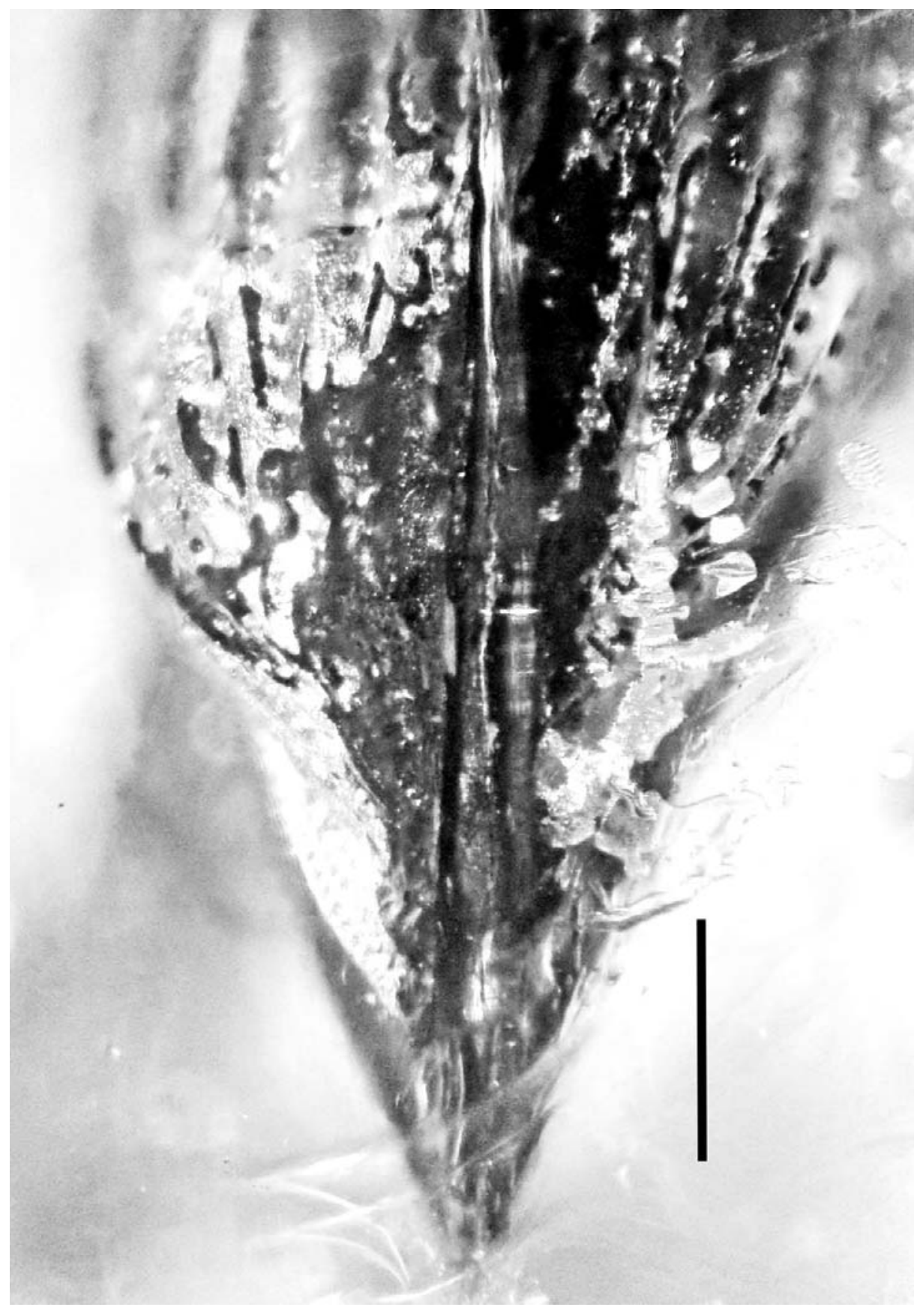

FIGURE 5. Dorsal view of tip of elytra of Brachycamacus gyrommatus in Dominican amber. Scale bar equals $0.6 \mathrm{~mm}$.

Poinar, G.O. Jr. and Mastalerz, M. 2000. Taphonomy of fossilized resins: determining the biostratinomy of amber. Acta Geologica Hispanica, 35:171-182.

Poinar, G.O., Jr. and Poinar. R. 1999. The Amber Forest. Princeton University Press, Princeton, New Jersey.

Schlee, D. 1990. Das Bernstein-Kabinett. Begleitheft zur Bernsteinausstellung im Museum am Löwentor, Stuttgart, 28:1-100.

Schoenherr, C.J. 1825. Continuatio Tabulae synopticae Familiae Curculionidum. Isis von Oken, 5:581-588.
Schoenherr, C.J. 1826. Curculionidum dispositio methodica cum generum characteribus, descriptionibus atque observationibus variis, seu prodromus ad synonymiae insectorum, 4. Fleischer. Lipsiae. X + $338 \mathrm{pp}$.

Schoenherr, C.J. 1840. Genera et species curculionidum, cum synonymia hujus familiae. Species novae aut hactenus minus cognitae, descriptionibus a Dom. Leonardo Gyllenhal, C.H. Boheman, et entomologiis aliis illustratae, 5(2). Paris:465-970. 
Sharp, D. 1891. Insecta. Coleoptera. Rhynchophora. Curculionidae. Attelabinae, Pterocolinae, Allocoryninae, Apioninae, Thecesterinae, Otiorhynchinae. p. 89-136. In Sharp D. and Champion, G.C. 18991911. Biologia Central-Americana, 4(3). 354 pp. +15 pl.

Thompson, R.T. 1992. Observations on the morphology and classification of weevils (Coleoptera, Curculionoidea) with a key to major groups. Journal of Natural History, 26: 835-891.

Wanat, M. and Boroviec, L. 1986. New genus of weevil (Coleoptera, Curculionidae) from Baltic amber. Polskie Pismo Entomologiczne, 56(2):243-247.

White, R.E. 1983. A Field Guide to the Beetles of North America. Houghton Mifflin Company, Boston.

Voss, E. 1953. Einige Rhynchophoren der Bernsteinfauna (Col.). Mitteilungen des geologischen Staatsinstitutes Hamburg, 22:119-140.
Voss, E. 1972. Einige Rüsselkäfer der Tertiärzeit aus baltischem Bernstein (Coleoptera, Curculionidea). Steenstupia, 2:167-181.

Yunakov, N.N. and Kirejtshuk, A.G. 2011. New genus and species of broad-nosed weevils from Baltic amber and notes on fossils of the subfamily Entiminae (Coleoptera, Curculionidae). ZooKeys, 160:7396.

Zherikhin, V.V. 1971. On the weevils (Insecta, Coleoptera) from the Baltic Amber. Trudy Palaeontologicheskogo Instituta, 130:197-209. [In Russian]

Zherikhin, V.V. and Egorov, A.B. 1991 Weevils (Coleoptera, Curculionidae) of the USSR Far East (a review of the subfamilies with description of new taxa). Institute of Biology and Soil science, Vladivostok. [In Russian]. 